\title{
OCCURRENCE AND DISTRIBUTION RANGE OF PARABLENNIUS PILICORNIS (ACTINOPTERYGII: PERCIFORMES: BLENNIIDAE) ALONG THE FRENCH MEDITERRANEAN COAST
}

\author{
Jérémy PASTOR ${ }^{*}$ and Patrice FRANCOUR** \\ University of Nice Sophia Antipolis, Faculty of Sciences, EA 4228 ECOMERS, Nice, France
}

Pastor J., Francour P. 2010. Occurrence and distribution range of Parablennius pilicornis (Actinopterygii: Perciformes: Blenniidae) along the French Mediterranean coast. Acta Ichthyol. Piscat. 40 (2): 179-185.

\begin{abstract}
Background. This study was initiated by the first observations of a coastal and benthic Atlantic fish speciesParablennius pilicornis (Cuvier, 1829) on the southern coasts of France. This fish has been recorded in the Mediterranean Sea since 1963, until recently colonizing its entire western part as well as the Adriatic Italian coasts. The aim of this study is to analyse and understand the dynamics of this invasion of $P$. pilicornis and to report its most recent sightings along the Provencal coast, France.

Materials and Methods. The data on the geographic distribution of P. pilicornis were either extracted from the relevant literature (majority of records) or contributed by the present authors. For the French coast, particularly the coast of Provence, the latter were data from underwater visual censuses, conducted during various studies or monitoring programs. The data were critically selected, organised, and analysed.

Results. Two dispersal pathways seem to have been followed by P. pilicornis. The first follows the coast of Morocco, Algeria, and Italy. The second pathway goes through the Spanish and French coasts. The meeting point of these two ways may be located on the coast of Provence, where we lastly observed this species in 2006. The emergence of $P$. pilicornis in the Mediterranean Sea corresponds clearly to a marginal dispersal. Colonization of the western Mediterranean took 43 years.

Conclusion. Since $P$. pilicornis is already present on the Italian coast of the Adriatic Sea, the colonization of the eastern Mediterranean seems imminent. Global change, including rising temperatures, seem to be a factor promoting the repartition area of this fish with tropical affinities.
\end{abstract}

Keywords: Atlantic migrant, marginal dispersal, fishes, Mediterranean, establishment, ringneck blenny, Blenniidae

\section{INTRODUCTION}

Ecosystem biodiversity is being altered at a worldwide scale by species loss due to extinction from human activities and species gain through intentional and accidental introductions (Sala et al. 2000). At the regional level, species gain usually equals or outpaces the losses due to extinction, suggesting that extinctions and invasions might offset one another with little net change in diversity (Sax and Gaines 2003). However, because different processes drive extinctions and invasion (e.g., overfishing versus ballast water transport), the types of species being gained and lost might differ (Byrnes et al. 2007). The combined effect of these two processes is altering the structure of coastal marine food webs, because most extinctions occur at high trophic levels, while most invasions are by species from lower trophic levels (Byrnes et al. 2007). Thus, introductions of exotic species affect plankton, macrophytes, shellfish, and crustaceans (Galil 2007).

The Mediterranean sea is currently facing dramatic changes, including change in native species distribution due to climatic modification (Francour et al. 1994, Bianchi 2007), harmful algal blooms linked to increasing eutrophication (Heisler et al. 2008), fishing activity (Farrugio et al. 1993), habitat fragmentation and destruction (Airoldi and Beck 2007), and non-indigenous species invasion (Galil 2008). Consequently, Mediterranean food webs are considered to be in an advanced state of ecological degradation (Coll et al. 2008).

The Mediterranean Sea is a semi-enclosed area with limited connection to two oceans: the Atlantic Ocean through the Strait of Gibraltar, and the Indian Ocean, accessed across the Red Sea through the Suez Canal, which was dug in 1869. Ben Rais Lasram and Mouillot (2009) identified the Mediterranean Sea as "the recipient of the greatest number of exotic species in the world", with an average of one introduction every four weeks over the past five years. Zenetos et al. (2008) mention one introduction every 9 days. According Streftaris et al. (2005), the majority of these introductions are due to fouling, the release of ballast water from ships, and aquacul-

\footnotetext{
* Correspondence: Correspondence: Dr Jérémy Pastor, Université de Nice Sophia-Antipolis, Faculté de Sciences, EA 4228 ECOMERS, Parc Valrose, BP 71, F-06108 Nice Cedex, France, Phone: +33 4920768 33. Fax: +33 4920768 49, e-mail: jeremy.pastor@unice.fr, **francour@unice.fr
} 
ture. However, other authors (Briggs 2007, Ben Rais Lasram and Mouillot 2009) observe that "the introduction of fish into the Mediterranean Sea by ships is surprisingly rare and fish aquaculture-mediated introductions do not occur". In the Mediterranean, 127 fish species are exotic, comprising 65 lessepsian immigrant species (Indo-Pacific origin) and 62 of Atlantic origin; the last studies carried out in Mediterranean record a total of 664 fish species (Ben Rais Lasram and Mouillot 2009). The introduction of fish from both the Atlantic Ocean and the Red Sea may increase the intensity of interactions between exotic and endemic fish fauna (Ben Rais Lasram and Mouillot 2009).

Although the number of lessepsian species is equivalent to the number of Atlantic species in the Mediterranean, the former has attracted a higher interest of scientists. Probably because the Mediterranean has been naturally linked to the Atlantic Ocean for a very long time, its fauna and flora are originally subjected to a strong Atlantic influence. The connection to the Red Sea is much more recent and the emergence of new lessepsian species is being actively followed (Galil 2007, 2008, Belmaker et al. 2009).

The migration through the Strait of Gibraltar has not been affected by humans. This is not true for lessepsian migrations since the building of the Suez Canal. Throughout geologic time, species range extension is a natural phenomenon that has played an important role in speciation and structure of present populations, and it cannot then be regarded as a biologic introduction induced by human activity. There is typically the case for migration by the Strait of Gibraltar.

The emergence of a species in a region where it has not been present can be made by marginal dispersal (stepwise range extension) or by remote dispersal (when there is a spatial discontinuity between its area of origin and the new area; Crisp 1958). However, periodic fluctuations at the limits of its range may occur in relation to particular climatic episodes. In the northern hemisphere, for example, species range limits can move to the north during warm episodes and to the south during cold episodes.

The current episode of global warming (largely attributed to human action) is sometimes inferred to explain the extension of geographical area of some species, and several examples of changes in limits range of fish species with Atlantic origin may be indicated in the Mediterranean: Acanthurus monroviae (Acanthuridae) (Hemida et al. 2004, Luiz-Júnior et al. 2004), Pomadasys incisus (Haemulidae) (Pastor et al. 2008), Seriola fasciata (Carangidae) (Massuti and Stefanescu 1993, Bradai et al. 2004, Corsini et al. 2006), Thalassoma pavo (Labridae) (Francour 1994), and "Kyphosus sectator" (=Kyphosus saltatrix; Kyphosidae) (Francour and Mouine 2008). Some populations can then evolve independently and allow the emergence of endemic species (speciation).

In this study we focus on a species of Blenniidae - the ringneck blenny, Parablennius pilicornis (Cuvier, 1829). Several studies have mentioned its presence in the Mediterranean Sea (Zander 1969, Bath 1977, Almeida et al. 1980, Catalano et al. 1985, Mercader 1988, Nieder 1988). Nevertheless, no work to date has put together these data to understand the dynamics of sightings of this fish in the Mediterranean. We propose to conduct a global study on existing observations in the literature, as well as the observations conducted in the field.

Since its description by Cuvier in 1829 (Froese and Pauly 2010) from a specimen captured on the Brazilian coast, Parablennius pilicornis has been currently renamed by several naturalists (see Bath 1977). P. pilicornis measures about $10 \mathrm{~cm}$, is omnivorous, and reported as frequenting rocky habitats down to 5-6 $\mathrm{m}$ of depth (Zander 1988). The species is gonochoric. Like in the majority of blenniids, the eggs are benthic and are protected by the male. A highly developed social and spawning behavior has been observed. The duration of the larval stage of this fish is about 33 days (31-37, on the average) (Beldade et al. 2007), while the egg incubation time is some $70 \mathrm{~h}$ at $23^{\circ} \mathrm{C}$ (Almeida et al. 1980).

\section{MATERIAL AND METHODS}

The data on the geographic distribution of Parablennius pilicornis, used in this paper were either extracted from the relevant literature (majority of records) or contributed by the present authors from other sources, including unpublished data. For the French coast, particularly the coast of Provence, these are supplemented by data from underwater visual censuses, conducted during various studies or monitoring programs that were not necessarily focused on this blenny. The data were critically selected, organised, and analysed.

\section{RESULTS}

The known geographic distribution of Parablennius pilicornis includes the western Mediterranean Sea and the eastern Atlantic Ocean, from the Bay of Biscay to South Africa (Zander 1969, 1988, Bath 1977, Almada et al. 2001). In the western Atlantic, the range of P. pilicornis is limited to the southern South American region, including Brazil and Patagonia (Bath 1977).

Since the first description of $P$. pilicornis by Cuvier (1829), several major faunistic surveys were performed in the Mediterranean (e.g., Canestrini 1872, Gourret 1897, Gibert 1913). They did not mention the presence of $P$. pilicornis. Similarly, several literature reviews conducted on blennies in the middle of the 20th century did not report this species (Zander 1969, 1988, Bath 1977). P. pilicornis has been observed for the first time in the temperate Atlantic Ocean at Hendaye in the Biscay Bay in 1957 (Bath 1977). Then it was observed near the Strait of Gibraltar at Rabat (Morocco) in 1967 (Bath 1977) and Lagos (South Portugal) in 1978 (Almeida et al. 1980; Table 1). The first observation of P. pilicornis in Mediterranean was made in 1963, from Algiers (Bath 1977; Table. 1). In 1968, the entire Algerian coast was colonized by this species (Zander 1969, Bath 1977). Presently, $P$. pilicornis occurs on the western part of the south coast of the Mediterranean, from the Strait of Gibraltar to Annaba in Algeria (Table 1). 
Year of first observations of Parablennius pilicornis in the Mediterranean and some observations in the temperate eastern Atlantic Ocean

\begin{tabular}{|c|c|c|c|}
\hline Locality & Country & Year & Reference \\
\hline Hendaye (Atlantic) & France & 1957 & Bath 1977 \\
\hline Lagos (Atlantic) & Portugal & 1978 & Almeida et al. 1980 \\
\hline Rabat (Atlantic) & Marocco & 1967 & Bath 1977 \\
\hline Capo Negro & Marocco & 1967 & Bath 1977 \\
\hline Oran & Algeria & 1968 & Zander 1969 \\
\hline Algier & Algeria & 1963 & Bath 1977 \\
\hline Tichy & Algeria & 1968 & Zander 1969 \\
\hline Annaba & Algeria & 1968 & Zander 1969 \\
\hline Torremolinos & Spain & 1967 & Bath 1977 \\
\hline Taramay & Spain & 1965 & Bath 1977 \\
\hline Ibiza & Spain & 1985 & Cardona and Elices 2002 \\
\hline Cabrera & Spain & 1992 & Ballesteros pers. com. \\
\hline Menorca & Spain & 1995 & Cardona and Elices 2002 \\
\hline Palamos & Spain & 1986 & Mercader 1988 \\
\hline Banyuls/mer & France & 1988 & Zander (unpublished) \\
\hline Cap d'Agde & France & 1987 & Louisy pers. com. \\
\hline Fos/mer & France & 1994 & Harmelin pers. com. \\
\hline Marseille Podetta & France & 1998 & Harmelin pers. com. \\
\hline Porquerolles & France & 2006 & Harmelin pers. com. \\
\hline Port-Cros & France & 2006 & This study \\
\hline Cap-Roux & France & 2006 & This study \\
\hline Monaco & Monaco & 2006 & This study \\
\hline Scandola & Corsica (France) & 2005 & This study \\
\hline Palerme & Sicily (Italy) & 1982 & Catalano et al. 1985 \\
\hline Finale Ligure & Italy & 1988 & Balma et al. 1989 \\
\hline Portofino & Italy & 2003 & Tunesi and Molinari 2005 \\
\hline Porto Cesareo & Italy & 2004 & Dufour et al. 2007 \\
\hline Torre Guaceto & Italy & 2004 & Dufour et al. 2007 \\
\hline Tremiti & Italy & $?$ & Dufour et al. 2007 \\
\hline Ravenna / Venice & Italy & 2005 & Santin and Willis 2007 \\
\hline
\end{tabular}

However it also occurs throughout the northern part of the and Scandola, and at very high densities on artificial reefs western basin of the Mediterranean, from the Strait of in Le Barcarès (Gulf of Lion) at the depth of $20 \mathrm{~m}$.

Gibraltar to the entire Italian coast (western Mediterranean and Adriatic), including Baleares, Sardinia, Corsica, and Sicily islands. No sighting was reported in Tunisia and in the eastern basin of the Mediterranean. In Adriatic, P. pilicornis reaches Venice in the north-west Adriatic Sea (Table 1), but it occurs only on the Italian side of the Adriatic Sea. Despite a regular monitoring on the Croatian coast, this species has not been reported yet (Marcelo Kovačić pers. com.).

Regular and annual monitoring performed in four marine protected areas along the French coast, allowed to date precisely the time of arrival of this species at Port-Cros, Cap Roux, Monaco, and Scandola (Corsica) (Table 1).

Our observations also provide new information on the bathymetric distribution of this species. Indeed, this fish was regarded as preferentially frequenting the area between 0 and $6 \mathrm{~m}$ depth (Zander 1988), whereas we have observed it at the depth of $25 \mathrm{~m}$ at Monaco, $15 \mathrm{~m}$ depth at Port-Cros

\section{DISCUSSION}

The usual difficulty of the systematics of Blenniidae can explain the high number of names synonymous with Parablennius pilicornis and the difficulty to identify clearly the geographic distribution of this fish. The diversified colour patterns that this fish may display during its life cycle may further increase the confusion. Four colour patterns are described:

- The standard pattern: the fish displays a light brown colour with of a series of white „ $\mathrm{H}^{\prime \prime}$ drawings on the body;

- The dark pattern: only for the spawning males and characterized by an almost black body; A black spot is present at the front of the dorsal fin;

- The white and black pattern: the fish displays a very clear colour, almost white; A dark brown strip runs from the eye to the base of caudal fin; A third line is present along the dorsal fin in the middle of the back. Fish exhibit- 
ing this pattern may be confused with Parablennius rouxi (Blenniidae), which is slimmer and smaller;

- The yellow pattern: the fish has a yellow uniform body. The identification of this species makes no doubt with this pattern.

Regardless of the pattern, the species can be identified based on the presence of honeycomb pattern on the cheeks. Apart from the dark pattern that characterizes the spawning males, no particular relation with the sex of the fish has been shown for other patterns.

Parablennius pilicornis was originally described (Cuvier 1829) from a specimen captured in Brazil. Since then, no study could decide between its eastern Atlantic origin or a western Atlantic origin. Nevertheless, LuizJúnior et al. (2004) suggested that this species was an amphi-Atlantic westward migrant. Indeed, it is commonly assumed that the place of origin of a particular species is where it reaches the largest area of occurrence (Joyeux et al. 2001, Luiz-Júnior et al. 2004). For P. pilicornis, the largest area of occurrence is clearly in the eastern Atlantic (Bath 1977, Zander 1988, Luiz-Júnior et al. 2004). Three hypotheses would allow explaining how $P$. pilicornis reached South American coast:

- The first hypothesis is that there was one population before the opening of the Atlantic Ocean. It was separated into two distinct populations during the formation of the mid-Atlantic ride. At some stage the populations were continuous and subsequently separated by the formation of unsuitable habitats inside their distributional range, without speciation (Luiz-Júnior et al. 2004).

- P. pilicornis has a planktonic larval duration of about 37 days at most (Beldade et al. 2007). With extremely favourable conditions, these larvae could cross the Atlantic Ocean. Indeed, $3000 \mathrm{~km}$ separate the Brazilian and African coasts with the Ascension Island and St. Peter and Paul Rocks that could serve as an intermediate relay. According to a genetic study, Carlin et al. (2003) suggested that Rypticus saponaceus (Serranidae) larvae can cover distances of as many as $2000 \mathrm{~km}$, while the larval stage is only 30 days. Finally, the oceanographic barriers to dispersal in the tropical Atlantic Ocean are expected to be variable in their effectiveness over geological time (Rocha 2003), and the effects of stochastic climatic events on the oceanic currents (Philander 1986, Joyeux et al. 2001, Carlin et al. 2003) could promote periods of favoured dispersion alternating with periods of isolation.

- Gerhardinger et al. (2006) warned that Brazilian blennies such as $P$. pilicornis were observed inhabiting ship hulls heading to Argentina and Africa. If this species is able to cross the Atlantic in holes or fouling of boats, this could explain its presence on both sides of the Atlantic Ocean. Indeed between 16th and 19th centuries, the maritime traffic between Africa and South America was very dense, especially because of the trans-Atlantic slave trade that could cause the introduction of $P$. pilicornis in the western Atlantic.

Although the last two hypotheses seem most likely, only genetic and phylogenetic studies would allow the dating of the separation between $P$. pilicornis populations associated with the eastern Atlantic Ocean and the western Atlantic Ocean.

Parablennius pilicornis arrived in the Mediterranean Sea through the Strait of Gibraltar (Fig. 1), the first observation being made at Algiers in 1963 (Bath 1977). In 43 years, it has colonized the entire western basin of the Mediterranean Sea. However there is no information about the Tunisian coast. An inventory of blennies was conducted in 1997 (Gharred et al. 1998) using landing net and trawl as sampling tools, but no P. pilicornis was observed. This may be due to the inadequate sampling method of catching blennies on rocky habitats, as scuba diving is more effective to observe them.

According to available data, it appears that the colonization of the western Mediterranean followed two ways. The southern way, allowed the colonization of the coasts of Morocco, Algeria, then Sicily. Twenty years have been necessary to reach the Sicily $(1600 \mathrm{~km}$ from the Strait of Gibraltar). This pathway was probably the starting route for the colonization of Sardinia and Corsica islands. From Sicily, the species has probably spread along the west coast of Italy up to the French border. Colonization continued from Sicily to the Adriatic Sea along the Italian coast. P. pilicornis have been observed during scuba diving monitoring in the marine reserves of Porto Cesareo (Ionian Sea), Torre Guaceto and Tremiti (Adriatic) (P. Guidetti; data published in Dufour et al. 2007). The northernmost observation was made near Venice (Santin and Willis 2007). The species is not yet present in Croatian waters (Marcelo Kovačić pers. com.). However, there is no doubt it will happen soon. The second pathway or northern route, allowed the colonization of Spanish and French coasts. It took more than 30 years for $P$. pilicornis to reach Marseille (1300 km from the Strait of Gibraltar) and the island of Minorca in the Balearic Islands $(900 \mathrm{~km}$ from the Strait of Gibraltar). This pathway appears slower than the southern route, probably due to adverse currents from Gibraltar to Marseilles (Somot et al. 2006).

After observations made in Port-Cros, Cap Roux, and Monaco in 2006, this area seems to be the meeting point of these two routes. Since a monitoring on these three sites was performed each year, we are sure that $P$. pilicornis appeared in 2006 and not before. The spreading of $P$. pilicornis across the Mediterranean clearly corresponds to a marginal dispersal (Crisp 1958). Human activities have not been a direct vector in this establishment; it is therefore difficult to classify it as a biological invasion (Ruiz et al. 2000).

The dynamics of colonization of the western Mediterranean by $P$. pilicornis followed an almost perfect timing. The exception was the observation made in 1988 by Balma et al. (1989) at Finale Ligure in the Gulf of Genoa. This observation appeared too early compared to those made in Portofino in 2003 (80 km from Finale Ligure) and Monaco in 2006 (90 km from Finale Ligure), two of the nearest localities. In the study conducted in 1988, Balma et al. (1989) observed only one specimen. Moreover, the observation was conducted in the Finale 


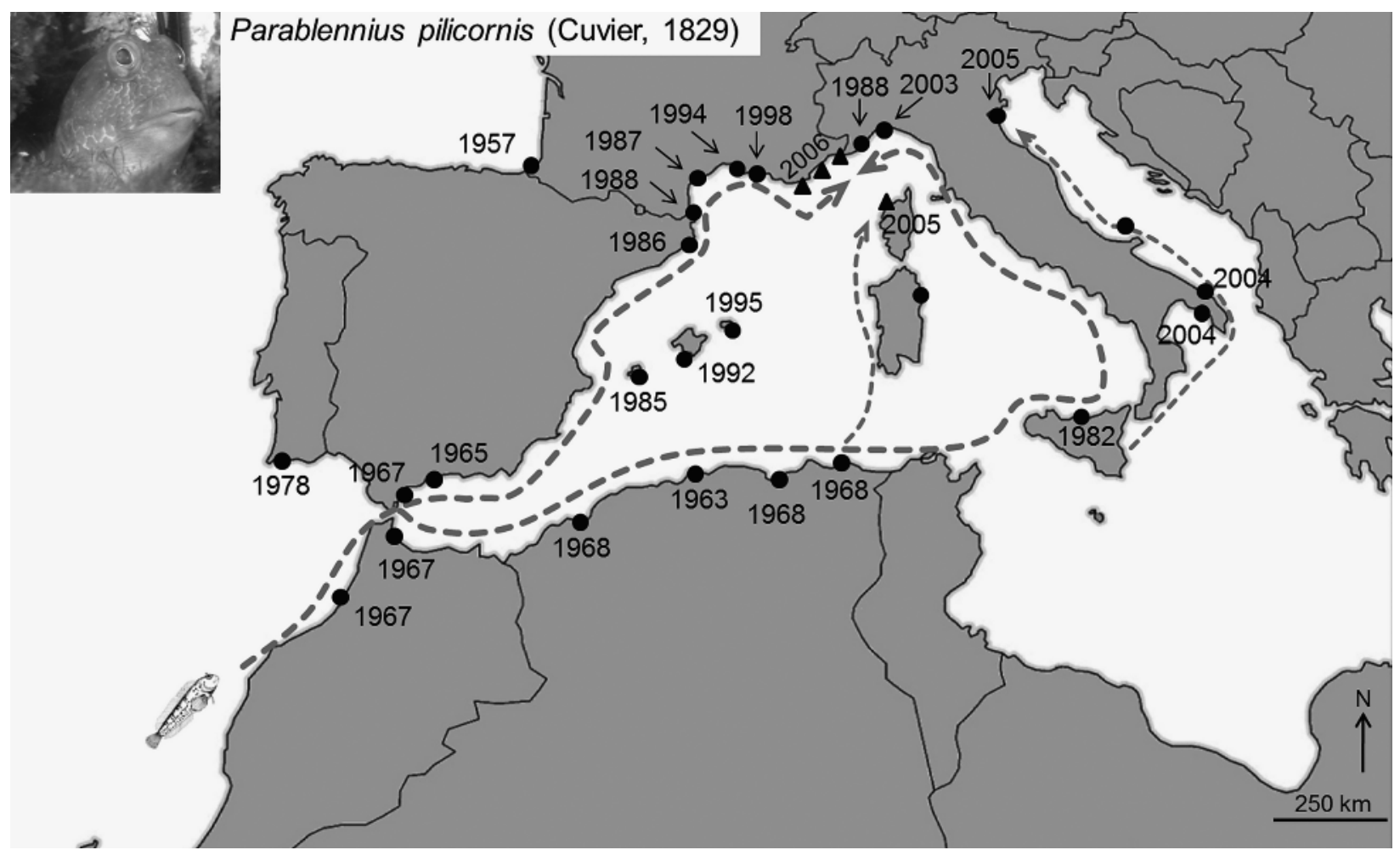

Fig. 1. Map of the western Mediterranean with dates of first observations of Parablennius pilicornis; The arrows indicate its potential dynamic of apparition in the zone; Triangles present data from this study

Ligure harbour. It is thus possible that in this case the introduction was only incidental. Indeed an introduction is only effective when the species is established. It is possible only if the entire fish life cycle can be completed, including reproduction, settlement and recruitment phases (e.g., Lodge et al. 2006). In 1988, P. pilicornis was present on the entire stretch from the Strait of Gibraltar to Sicily on the southern colonization route, reaching the Franco-Spanish border on the northern route. Given the ability of this fish to travel in/on the hull of ships (Gerhardinger et al. 2006), an introduction in the Finale Ligure harbour via a boat from a harbour already colonized (in Spain or in Sicily, for example) is then possible. There is no information on the future of this species in this locality. Fifteen years were needed, however, to colonize proximal areas (Monaco and Portofino), this would support our hypothesis of no establishment at that time.

We can try to explain why its arrival in the Mediterranean has begun not earlier than in the 1960s. Indeed, given the original distribution area of $P$. pilicornis in the tropical- and sub-tropical Atlantic Ocean (Bath 1977), the first possible explanation is that this species responds positively to the global change. As all other seas around the world, the Mediterranean Sea has currently been warming up. For the last 30-40 years, the temperature of the western Mediterranean Sea has been rising in its deep- (Bethoux et al. 1990) and surface waters (Diaz-Almela et al. 2007). We believe that $P$. pilicornis can now find a suitable environment in the Mediterranean Sea for its growth and expansion.

Parablennius pilicornis had a relatively slow dispersal in the Mediterranean. Several lessepsian immigrant species showed high rate of dispersal; for example, Fistularia commersonii (Fistulariidae) have colonized the sea from east to west in less than 10 years (Dulčić et al. 2008). It is possible that the competition with other blenny species slowed down the dispersal of $P$. pilicornis. However, this species seems to benefit from the proliferation of artificial habitats. For example, on the French Catalan coast in the Gulf of Lion (Le Barcarès, France), P. pilicornis is the most abundant species on the newly ( 5 years) set up artificial reefs (Pastor unpublished data). This fish is highly opportunistic and can take advantage of new, artificial habitats that promote high densities.

The emergence of $P$. pilicornis in Mediterranean fish populations raises the question of its impact on other species of blennies, but also other small benthic fishes inhabiting rocky bottoms. Blenny inventories were very rare before the emergence of $P$. pilicornis, so it is difficult to track back its impact on the colonized ecosystems. The voracity of this fish and its strong territoriality make it a great competitor for other species from the same habitat. To answer the essential question of the response of an ecosystem to the introduction of a species, it may be possible to conduct monitoring in areas that have not been colonized yet. Croatian coast and Eastern Mediterranean can be good study sites in that regard and we think they will soon be colonized.

The first observation of a species will of course depend on the presence or absence of the species in the study site, but also on the monitoring intended to detect it. This could explain the fact that Parablennius pilicornis was observed in Algiers four years earlier than in the 
Alboran Sea (Zander 1969, Bath 1977). This study emphasizes again the need of establishing a global monitoring activity across the Mediterranean to detect the arrival of new species in this sea. It is highly probable that in the next 10 years, we will observe the colonization of the eastern Mediterranean by $P$. pilicornis.

\section{ACKNOWLEDGEMENTS}

We thank Barbara Köck and Ronan Lucas for their help in our bibliographic searches. The authors are also grateful for the relevant information to Philippe Lenfant, Jean-Georges Harmelin, Paolo Guidetti, Enrique Ballesteros, Marcelo Kovačić, Leonardo Tunesi, and Patrick Louisy. We also thank Camille Mellin for English proofreading. We are also grateful to the anonymous reviewer for their most helpful comments on an earlier draft of this article.

\section{REFERENCES}

Airoldi L., Beck M.W. 2007. Loss, status and trends for coastal marine habitats of Europe. Oceanography and Marine Biology: An Annual Review 45: 345-405.

Almada V.C., Oliveira R.F., Gonçalves E.J., Almeida A.J., Santos R.S., Wirtz P. 2001. Patterns of diversity of the north-eastern Atlantic blenniid fish fauna (Pisces: Blenniidae). Global Ecology and Biogeography 10 (4): 411-422. DOI: 10.1046/j.1466-822X.2001.00244.x.

Almeida A.J., Gomes J.A., Ré P. 1980. Trois Blenniidae nouveaux pour la faune du Portugal (Pisces: Perciformes). Tethys 9 (3): 235-241.

Balma G., Bath H., Delmastro G.B. 1989. A new record of Parablennius pilicornis (Cuvier, 1829) from the Italian seas (Osteichthyes: Blennidae). Nova Thalassia 10: 99-102.

Bath H. 1977. Revision der Blenniini (Pisces: Blennidae). Senckenbergiana Biologica 57 (4-6): 167-234.

Beldade R., Pedro T., Gonçalves E.J. 2007. Pelagic larval duration of 10 temperate cryptobenthic fishes. Journal of Fish Biology 71 (2): 376-382. DOI: $10.1111 /$ j.1095-8649.2007.01491.x.

Belmaker J., Brokovich E., China V., Golani D., Kiflawi M. 2009. Estimating the rate of biological introductions: Lessepsian fishes in the Mediterranean. Ecology 90 (4): 1134-1141. DOI: 10.1890/07-1904.1.

Ben Rais Lasram F., Mouillot D. 2009. Increasing southern invasion enhances congruence between endemic and exotic Mediterranean fish fauna. Biological Invasions 11 (3): 697-711. DOI: 10.1007/s10530-008-9284-4.

Bethoux J.P., Gentili B., Raunet J., Tailliez D. 1990. Warming trend in the western Mediterranean deep water. Nature 347 (6294): 660-662. DOI: 10.1038/347660a0.

Bianchi C.N. 2007. Biodiversity issues for the forthcoming tropical Mediterranean Sea. Hydrobiologia 580 (1): 7-21. DOI: $10.1007 / \mathrm{s} 10750-006-0469-5$.

Bradai M.N., Quignard J.P., Bouain A., Jarboui O., Ouannes-Ghorbel A., Ben Abdallah L., Zaouali J., Ben Salem S. 2004. Ichtyofaune autochtone et exotique des côtes tunisiennes: recensement et biogéographie. Cybium 28 (4): 315-328.
Briggs J.C. 2007. Marine biogeography and ecology: invasions and introductions. Journal of Biogeography 34 (2): 193-198. DOI: 10.1111/j.1365-2699.2006.01632.x.

Byrnes J.E., Reynolds P.L., Stachowicz J.J. 2007. Invasions and extinctions reshape coastal marine food webs. PLoS ONE 2 (3): e295. DOI: 10.1371/journal.pone.0000295.

Canestrini G. 1872. Fauna d'Italia. Parte terza. Pesci. [Fauna of Italy. Part three. Fishes.] Vallardi tipografo-editore, Milano. [In Italian.]

Cardona L., Elices M. 2002. Els peixos. Vol. I. Enciclopedia de Menorca. Obra Cultural de Menorca.

Carlin J.L., Robertson D.R., Bowen B.W. 2003. Ancient divergences and recent connections in two tropical Atlantic reef fishes Epinephelus adscensionis and Rypticus saponaceous (Percoidei: Serranidae). Marine Biology 143 (6): 1057-1069. DOI: 10.1007/s00227-003-1151-3.

Catalano E., Vitturi R., Zava B., Macaluso M. 1985. Ritrovamento di Parablennius pilicornis (Cuvier, 1829) nelle acqua italiane e suo cariotipo (Pisces Blennidae ). [The finding of Parablennius pilicornis (Cuvier, 1829) in the sea water of the Italian coasts, and its karyotype (Pisces Blenniidae).] Atti della Società Italiana di Scienze Naturali e del Museo Civico di Storia Naturale di Milano 126 (3-4): 155-164. [In Italian.]

Coll M., Lotze H.K., Romanuk T.N. 2008. Structural degradation in Mediterranean Sea food webs: Testing ecological hypotheses using stochastic and mass-balance modelling. Ecosystems 11 (6): 939-960. DOI: 10.1007/s10021-008-9171-y.

Corsini M., Margies P., Kondilatos G., Economidis P.S. 2006. Three new exotic fish records from the SE Aegean Greek waters. Scientia Marina 70 (2): 319-323.

Crisp D.J. 1958. The Spread of Elminius modestus Darwin in north-west Europe. Journal of the Marine Biological Association of the United Kingdom 37 (2): 483-520.

Diaz-Almela E., Marbà N., Duarte C.M. 2007. Consequences of Mediterranean warming events in seagrass (Posidonia oceanica) flowering records. Global Change Biology 13 (1): 224-235. DOI: 10.1111/j.1365-2486.2006.01260.x.

Dufour F., Guidetti P., Francour P. 2007. Comparaison des inventaires de poissons dans les aires marines protégées de Méditerranée : influence de la surface et l'ancienneté. Cybium 31 (1): 19-31.

Dulčić J., Scordella G., Guidetti P. 2008. On the record of the Lessepsian migrant Fistularia commersonii (Ruppell, 1835) from the Adriatic Sea. Journal of Applied Ichthyology 24 (1): 101-102. DOI: 10.1111/j.1439-0426.2007.01022.x.

Farrugio H., Olliver P., Biagi F. 1993. An overview of the history, knowledge, recent and future research trends in Mediterranean fisheries. Scientia Marina 57: 105-119.

Francour P., Boudouresque C.F., Harmelin J.G., HarmelinVivien M., Quignard J.P. 1994. Are the Mediterranean waters becoming warmer? Information from biological indicators. Marine Pollution Bulletin 28 (9): 523-526.

Francour P., Mouine N. 2008. First record of Kyphosus sectator (Kyphosidae) along the French Mediterranean coast. Cybium 32 (3): 275-276.

Froese R., Pauly D. (eds.) 2010. FishBase. [version 09/2010] http://www.fishbase.org. 
Galil B.S. 2007. Loss or gain? Invasive aliens and biodiversity in the Mediterranean Sea. Marine Pollution Bulletin 55 (7-9): 314-322. DOI: 10.1016/j.marpolbul.2006.11.008.

Galil B.S. 2008. Alien species in the Mediterranean Sea-which, when, where, why? Hydrobiologia 606 (1): 105-116. DOI: $10.1007 / \mathrm{s} 10750-008-9342-z$.

Gerhardinger L.C., Hostim-Silva M., Barreiros J.P. 2006. Empty mussel shells on mariculture ropes as potential nest places for the blenny Hypleurochilus fissicornis (Perciformes: Blenniidae). Journal of Coastal Research 2 (SI 39): 1202-1204.

Gharred T., Ktari M.H., Ben Salem M. 1998. Inventaire systématique des côtes tunisiennes. Cybium 22 (2): 99-105.

Gibert M. 1913. Fauna ictiologica de Catalunya. J. Bartra Laborde, Barcelona.

Gourret P. 1897. Les étangs saumâtres du midi de la France et leurs pêcheries. Annales du museum d'histoire naturelle de Marseille 5 (1): 1-386.

Heisler J., Glibert P.M., Burkholder J.M., Anderson D.M., Cochlan W., Dennison W.C., Dortch Q., Gobler C.J., Heil C.A., Humphries E., Lewitus A., Magnien R., Marshall H.G., Sellner K., Stockwell D.A., Stoecker D.K., Suddleson M. 2008. Eutrophication and harmful algal blooms: A scientific consensus. Harmful Algae 8 (1): 3-13. DOI: 10.1016/j.hal.2008.08.006.

Hemida F., Diatta Y., Golani D., Ben Souissi J., Guélorget O., Capapé C. 2004. On the occurrence of the Monrovian surgeonfish, Acanthurus monroviae Steindachner, 1876 (Osteichthyes: Acanthuridae) off the coast of Algeria (southern Mediterranean). Acta Adriatica 45 (2): 181-185.

Joyeux J.-C., Floeter S.R., Ferreira C.E.L., Gasparini J.L. 2001. Biogeography of tropical reef fishes: the South Atlantic puzzle. Journal of Biogeography 28 (7): 831-841. DOI: 10.1046/j.1365-2699.2001.00602.x.

Lodge D.M., Williams S., MacIsaac H.J., Hayes K.R., Leung B., Reichard S., Mack R.N., Moyle P.B., Smith M., Andow D.A., Carlton J.T., McMichael A. 2006. Biological invasions: Recommendations for US policy and management. Ecological Applications 16 (6): 2035-2054.

Luiz-Júnior O.J., Floeter S.R., Gasparini J.L., Ferreira C.E.L., Wirtz P. 2004. The occurrence of Acanthurus monroviae (Perciformes : Acanthuridae) in the south-western Atlantic, with comments on other eastern Atlantic reef fishes occurring in Brazil. Journal of Fish Biology 65 (4): 1173-1179. DOI: $10.1111 / \mathrm{j} .0022-1112.2004 .00519 . x$.

Massuti E., Stefanescu C. 1993. First record of Seriola fasciata (Bloch, 1793) (Osteichthyes, Carangidae) in the Mediterranean. Journal of Fish Biology 42 (1): 143-144. DOI: 10.1111/j.1095-8649.1993.tb00312.x.

Mercader L. 1988. Parablennius pilicornis (Cuvier, 1929) (Pisces, Blenniidae), primera citacio pel mar Catala (Mediterrania NO). Miscelanea Zoologica 12: 374-377. [In Catalan.]

Nieder J. 1988. Zum Vorkommen von Scartella cristata (L.) und Parablennius pilicornis (Cuv.) (Teleostei, Blenniidae) an der nordspanischen Mittelmeerküste. Zoologischer Anzeiger 220 (3-4): 144-150.

Pastor J., Astruch P., Prats E., Dalias N., Lenfant P. 2008. Premières observations en plongée de Pomadasys incisus
(Haemulidae) sur la côte catalane française. Cybium 32 (2): 185-186.

Philander S.G.H. 1986. Unusual conditions in the tropical Atlantic Ocean in 1984. Nature 322 (6076): 236-238. DOI: $10.1038 / 322236 \mathrm{a} 0$.

Rocha L.A. 2003. Patterns of distribution and processes of speciation in Brazilian reef fishes. Journal of Biogeography 30 (8): 1161-1171. DOI: 10.1046/j.1365-2699.2003.00900.x.

Ruiz G.M., Rawlings T.K., Dobbs F.C., Drake L.A., Mullady T., Huq A., Colwell R.R. 2000. Global spread of microorganisms by ships. Nature 408 (6808): 49-50. DOI: 10.1038/35040695.

Sala O.E., Chapin F.S.III, Armesto J.J., Berlow E., Bloomfield J., Dirzo R., Huber-Sanwald E., Huenneke L.F., Jackson R.B., Kinzig A., Leemans R., Lodge D.M., Mooney H.A., Oesterheld M., Poff N.L., Sykes M.T., Walker B.H., Walker M., Wall D.H. 2000. Global biodiversity scenarios for the year 2100. Science 287 (5459): 1770-1774. DOI: 10.1126/science.287.5459.1770.

Santin S., Willis T.J. 2007. Direct versus indirect effects of wave exposure as a structuring force on temperate cryptobenthic fish assemblages. Marine Biology 151 (5): 1683-1694. DOI: 10.1007/s00227-006-0586-8.

Sax D.F., Gaines S.D. 2003. Species diversity: from global decreases to local increases. Trends in Ecology and Evolution 18 (11): 561-566. DOI: 10.1016/s0169-5347(03)00224-6.

Somot S., Sevault F., Déqué M. 2006. Transient climate change scenario simulation of the Mediterranean Sea for the twenty-first century using a high-resolution ocean circulation model. Climate Dynamics 27 (7-8): 851-879. DOI: $10.1007 / \mathrm{s} 00382-006-0167-\mathrm{z}$.

Streftaris N., Zenetos A., Papathanassiou E. 2005. Globalisation in marine ecosystems: The story of non-indigenous marine species across European seas. Oceanography and Marine Biology_An Annual Review 43: 419-453.

Tunesi L., Molinari A. 2005. Species richness and biogeographic outlines of the fish assemblage of the Portofino marine protected area (Ligurian Sea). Biologia Marina Mediterranea 12 (1): 116-123.

Zander C.D. 1969. Mitteilung über die Verbreitung und Ökologie von Blennioidei des Mittelmeeres (Pisces). Mitteilungen aus dem Hamburgischen Zoologischen Museum und Institut 66: 59-63.

Zander C.D. 1988. Blennidae. Pp. 1096-1108. In: Whitehead P.J.P., Bauchot M.-L., Hureau J.-C., Nielsen J., Tortonese E. (eds.) Fishes of the North-eastern Atlantic and the Mediterranean. Vol. 3 UNESCO, Paris.

Zenetos A., Meriç E., Verlaque M., Galli P., Boudouresque C.F., Giangrande A., Çınar M.E., Bilecenoğlu M. 2008. Additions to the annotated list of marine alien biota in the Mediterranean with special emphasis on Foraminifera and parasites. Mediterranean Marine Science 9 (1): 119-165.

Received: 4 January 2010

Accepted: 18 August 2010

Published electronically: 15 December 2010 